PART II. PHYSICAL ACTIVITY OF SOCIAL AND PROFESSIONAL GROUPS

DZIAŁ II. AKTYWNOŚĆ FIZYCZNA GRUP SPOŁECZNYCH I ZAWODOWYCH

\title{
SOME BENEFICIAL PSYCHOLOGICAL ASPECTS OF PHYSICAL ACTIVITY IN NATURE - QUESTIONS ARISING FROM THE NARRATIVE REVIEW
}

\section{WYBRANE KORZYSTNE ASPEKTY AKTYWNOŚCI FIZYCZNEJ W NATURZE - PYTANIA PO PRZEGLĄDZIE ŹRÓDEŁ}

\author{
Klaudia Zusková ${ }^{1(\mathrm{~A}, \mathrm{E}, \mathrm{F})}$ \\ ${ }^{1}$ Institute of Physical Education and Sport, Pavol Jozef Šafárik University in Košice, Slovakia
}

Authors' contribution Wkład autorów: A. Study design/planning zaplanowanie badań B. Data collection/entry zebranie danych C. Data analysis/statistics dane - analiza i statystyki D. Data interpretation interpretacja danych E. Preparation of manuscript przygotowanie artykułu F. Literature analysis/search wyszukiwanie i analiza literatury G. Funds collection zebranie funduszy
Tables: 0

Figures: 0

References: 25

Submitted: 2021 Jan 10

Accepted: 2021 March 24

\section{Summary}

Human interaction with nature represents one of the basic pillars of healthy behavior. This can be strengthened by physical activity (PA) in nature, also called green exercise or outdoor PA. The aim of the work is to assess the impact of PA in nature on selected psychologically beneficial aspects of mental health. Subsequently, the paper discusses the following questions: 1) Are there any differences in the impact on mental health between outdoor and indoor PA?; 2) What are the recommendations for the minimum doses of PA in nature to improve or strengthen mental health? Despite large amounts of original research and many meta-analyses, as well as systemic reviews, we cannot clearly point to a convincing effect of PA in nature on mental health compared to indoor PA. Reviewed material points out the problem of heterogeneous study design, lack of quantitative findings and gaps in the evidence for long-term effects of PA in nature on mental health. Due to discrepancies in terminology, uniform conclusions could not be properly reached. There is a lack of meta-analytical studies specifying the type and intensity of PA in nature required to achieve an effect for a particular indicator of mental health.

Keywords: physical activity, nature, mental health, green exercise, outdoor, psychological aspects

\section{Streszczenie}

Interakcja człowieka z natura stanowi jeden z filarów zdrowego stylu życia. Może ona zostać wzmocniona przez aktywność fizyczną na łonie natury, którą można również nazwać zielonymi ćwiczeniami albo plenerową aktywnością fizyczną. Celem niniejszego opracowania jest przeprowadzenie oceny plenerowej aktywności fizycznej w związku z korzyściami psychologicznymi dla zdrowia psychicznego. Następnie, w artykule omówiono następujące kwestie: 1) Czy sa różnice we wpływie na zdrowie psychiczne pomiedzy aktywnościa fizyczna we wnętrzach i na świeżym powietrzu?; 2) Jakie są minimalne dawki aktywności fizycznej na świeżym powietrzu zalecane do osiągnięcia poprawy albo wzmocnienia zdrowia psychicznego? Pomimo dużej ilości badań i meta analiz, a także opracowań systemowych, nie jest możliwe przekonujące wskazanie wpływu aktywności fizycznej na świeżym powietrzu na zdrowie psychiczne w porównaniu do aktywności fizycznej wykonywanej we wnętrzach. Materiał poddany przegladowi wskazuje na problem heterogenicznego projektu badania, brak wyników kwantytatywnych i luki w dowodach na długofalowe skutki zielonej aktywności fizycznej na zdrowie psychiczne. Ze względu na rozbieżność terminologii, jednorodne wnioski były niemożliwe do wyciągnięcia. Brakuje badań meta analitycznych doprecyzowujących typy i intensywność aktywności fizycznej na świeżym powietrzu w celu osiągnięcia skutku dla konkretnego wskaźnika zdrowia psychicznego.

Słowa kluczowe: aktywność fizyczna, natura, zdrowie psychiczne, zielone ćwiczenia, plener, aspekty psychologiczne 


\section{Introduction}

Human interaction with nature has changed dramatically in recent centuries. It reflects people's current values in the environmental context. Those who are more connected to nature tend to experience more positive effects, vitality, and life satisfaction compared to those less connected [1]. These categories represent subjective well-being and happiness in positive psychology [2]. Blue-green spaces and physical activity (PA) have been shown to be beneficial to mental health and mitigate the effects of the various forms of lockdowns in place during the COVID-19 pandemic [3]. Nature's capabilities for restitution, aesthetic satisfaction, social interaction and health-promoting PA represent factors of the physical environment that can enhance healthy behavior [4]. The effects described above are anchored in the concept of mental health. "Mental health includes subjective well-being, perceived self-efficacy, autonomy, competence, intergenerational dependence and recognition of the ability to realize one's intellectual and emotional potential. The concept of mental health has also been defined as a state of well-being whereby individuals recognize their abilities, are able to cope with the normal stresses of life, work productively and fruitfully, and make a contribution to their communities" [5].

The terminology describing the natural environment in connection with PA is ambiguous. In connection with an analysis of works concerning the benefits of interaction with nature, Keniger et al. [6] divided the naturalness of the environment into six categories: indoor - inside a building; urban - a landscape dominated by built form; fringe - the area immediately surrounding a town or a city; production - a landscape of agricultural lands; wilderness - an area where human influence is low; and specific types and cases where the object of the interaction is defined with no particular setting. Gladwell et al. [4], in their review, analyze the benefits of PA from the point of view of the great outdoors which includes forests, seaside, countryside, parks, local green areas and gardens. Commonly used terms are green space, blue-green space, natural environment, nature or the great outdoors. Hartig et al. [7] points to this problem in the research methodologies addressing green environment or nature. The use of terms is not uniform.

PA can be undertaken in different ways, such as walking, cycling, sports and active forms of recreation. PA can also be undertaken at work and around the home [8]. A more general definition by World Health Organization (WHO) [8] defines PA as any bodily movements produced by skeletal muscles that requires energy expenditure. Exercise is a subcategory of PA. A broader definition of PA is conceptualized by Piggin [9] as involving "people moving, acting and performing within culturally specific spaces and contexts, and influenced by a unique array of interests, emotions, ideas, instructions and relationships". For PA in nature, Barton and Pretty [10] use the term "green exercise", while Yeh et al. [11] use "green physical activity". In order to attain credible outcomes, uniform criteria need to be adopted for the types of PA in nature.

The interaction of humans with nature influences mental health $[1,3,6]$, just as PA influences mental health $[8,12]$. These are two fundamental premises forming the basis for the implicit premise that PA in nature influences mental health. That premise raises the questions that this paper aims to articulate and answer.

\section{Aim of the work}

The aim of the work is to assess the impact of PA in nature on selected psychologically beneficial aspects of mental health. The review uses Internet literature and scientific databases, primarily in the fields of psychology, sports, public health and environmental sciences. Subsequently, the paper discusses the following questions: 1) Are there any differences in the impact on mental health between outdoor and indoor PA?; 2) What are the recommendations for the minimum doses of PA in nature to improve or strengthen mental health?

\section{Brief description of the status of knowledge}

Direct interaction of PA with nature (e.g. not a room with wallpaper depicting nature) improves mental well-being, relieves stress, increases positive mood, improves life skills, reduces mental fatigue and aggression, and increases concentration, self-esteem and perceived health $[4,10,13]$. In the last decade, there have been a growing number of studies demonstrating that the health and well-being benefits of green exercise provide greater physical and mental health benefits than either PA or contact with nature alone [14].

An ecological dynamics perspective emphasizes the multiple dimensions of behaviors and the constraints on activities in the environment to understand the psychological benefits of PA in nature or green exercise [11,13]. This comprehensive theoretical framework examines the effects of PA in nature and other influential factors, such as different age groups, various levels of engagement, diverse natural environments, activity duration, type and degrees of PA, performers' skill levels and the level of adventure and difficulty of the challenge [11]. 


\section{Are there any differences in the impact on mental health between outdoor and indoor PA?}

Thompson Coon et al. [15] reviewed in depth the relevant literature throughout 2010. Due to the heterogeneity of identified studies, a narrative synthesis had to be utilized. The outcomes formed a key contribution in this area upon which Eigenschenk et al. [16] and Lahart et al. [17] developed their systematic reviews. Thompson Coon et al. [15] concluded that in comparison with indoors, exercising in natural environments led to greater feelings of revitalization and positive engagement, decreases in tension, confusion, anger and depression, and increases in energy. Exercising outdoors - as compared to indoor exercising - stimulated more of it in the future. Self-reported mental well-being immediately following outdoor exercise was more positive than the reported well-being following exercise indoors. Unfortunately, the methodology used to assess the outcomes and the heterogeneity of the measured activities described in the literature means that the conclusions lack credibility. Eigenschenk et al. [16] introduced a group of six social impact categories and other benefits derived from outdoor sports. These are physical health, mental health and well-being, education and lifelong learning, active citizenship, crime reduction, and anti-social behavior. The findings underscored the positive impact of outdoor sports on physical and mental health, especially for affective states and self-development, as well as for well-being, quality of life, happiness and life satisfaction.

Lahart et al. [17] placed in doubt the results published by Thompson Coon et al. [15], who observed stronger associations between outdoor exercising and selected indicators of mental health. Lahart et al. [17], taking into account only studies with experimental or quasi-experimental designs, reviewed the period from 2010 to 2018. Causal relationships to health outcomes were compared between green exercise (including virtual green exercise) and indoor exercise. Significant statistical differences were observed for the positive effect of green exercise on valence and enjoyment, but not for emotion, perceived exertion, exercise intensity, and biological markers. The evidence indicating that green exercise is more beneficial than indoor exercise was found to be insufficient. Larger and better-designed studies need to be conducted to establish whether exercise in nature is more beneficial compared to indoor exercise.

Greater health and mental well-being benefits are achieved through PA in the natural environment than otherwise $[10,14,15]$. Green exercise intervention programs can play an important role in facilitating well-being [14]. Taking into consideration the association between exposure to nature and mental health, a question arises: What role does nature play in the association between PA and the strengthening of mental health? Based on the previously referenced research findings comparing outdoor green exercising and indoor exercising, it is clear that nature is an intervening variable facilitating the impact of exercise on mental health. Applying the knowledge of the association between outdoor time and increasing levels of moderate-to-vigorous PA (MVPA), Bélanger et al. [18] examined whether MVPA moderates or mediates the relationship between outdoor time and positive mental health in adolescents. This research raises the following question: What role does PA play in the association between exposure to nature and strengthening of mental health? Mediation analysis showed small indirect mediation and no direct mediation of MVPA on the effect of outdoor time on mental health. Although the statistical procedures in the research did not show clear significance, outdoor time could promote positive mental health among younger people through increases in PA. Future studies in this field should continue [18].

The research conducted during the last two decades has not conclusively determined that outdoor green exercising increases mental health benefits over indoor exercising [15-17]. Hypothetically, we could predict a greater impact of outdoor green exercising on psychological indicators of mental health $[4,15,16]$. This cannot be done, however, due to the heterogeneous study designs of the original papers and the argument that the mechanisms and main features of green exercise that improve well-being are not based on quantitative findings.

\section{What are the recommendations for the minimum doses of PA in nature to improve or strengthen mental health?}

Recommendations on PA for health by WHO [8] are: 1) adults aged 18-64 years should undertake at least 150-300 minutes of moderate-intensity aerobic PA per week or at least 75-150 minutes of vigorous-intensity aerobic PA per week, or an equivalent combination of moderate-intensity and vigorous-intensity activity; 2) for additional health benefits, adults should increase their moderate-intensity aerobic PA to 300 minutes per week, or engage in 150 minutes of vigorous-intensity aerobic PA per week, or an equivalent combination of moderateintensity and vigorous-intensity activity; and 3) muscle-strengthening activities involving major muscle groups should be done on two or more days per week.

The four main criteria for the creation of PA health programs are frequency, intensity, time and type (FITT). Haskel et al. [19] recommend that healthy adults aged 18-65 years engage in moderate-intensity aerobic 
(endurance) PA for a minimum of 30 minutes five days per week or vigorous-intensity aerobic PA for a minimum of 20 minutes three days per week. The FITT principle is missing an important component - fun or enjoyment. Incorporating a behavioral model in exercise may increase adherence to exercise regimes [20]. Green exercise may help motivate individuals to undertake PA by increasing enjoyment and providing escapism from everyday life. Decreasing the perception of effort and increasing motivation both support behavior change [4]. Social engagement also plays an important role [16].

A review by Meredith et al. [21] defined a dose of time in nature that could be prescribed to college-age students as a preventive and supportive mental health and well-being intervention. A dose of as little as 10-20 minutes and up to 50 minutes of sitting or walking in a diverse array of natural settings has a significant and positive impact.

What is the appropriate dosage of PA in nature in the short term for selected indicators of mental health? The term "dose of green exercise" represents the relationships between duration of exposure, intensity of activity, and type of green space [10]. Dose - response curves for the duration of exposure show distinct U-curves for both self-esteem and mood. The greatest changes come from five minutes of green exercise activity. The changes are lower for 10-60 minutes and half-day but rise again for the whole day duration. For self-esteem, the greatest change is for light activity and then declines with growing intensity. For mood, the response is again greatest for light intensity, declining to the lowest levels for moderate intensity, and then rising again for vigorous activity.

Analysis of urban space, countryside and woodland habitats does not indicate great differences in effect. Waterside habitats showed the greatest changes according to Barton and Pretty [10]. This applies to both genders. The improvement in self-esteem declines with aging. The greatest change was in the youngest age group of $<30$ years (other groups were 31-50 years, 51-70 years, and $>70$ years), whereas mood showed an inverted U-curve with the greatest changes in the middle age groups. Similar findings in a multi-study analysis are confirmed by Rogerson et al. [14]. Greater improvements in well-being due to acute bouts of nature and green exercise exposure occur in people with poorer mental health $[10,14]$. The results of medium-term green exercise suggest the same effects even in older adults [14]. Three big multi-study analyses confirm that acute bouts of nature exposure were associated with an increased positive effect on well-being [10,14,22].

What is a dose of green exercise from a longer time perspective? People need to spend at least two hours per week in blue-green spaces according to a study of more than 20,000 persons; otherwise, their well-being decreases significantly [23]. Medium-term green exercise interventions of 12 and 26 weeks duration can play an important role in facilitating well-being [14]. A study by Rogerson et al. [14], based on a quasi-experimental design without a control group, concluded that future research should address whether green exercise interventions are most effective at improving specific well-being facets such as eudemonic and hedonic components. The Eigenschenk et al. [16] review revealed gaps in the evidence base, which are especially notable for the long-term effects that outdoor sports can have on personal and social development.

In discussing the doses of green exercise required to achieve positive mental benefits, the type of PA in nature should be also discussed. All types of green exercise activities improve self-esteem and negative mood subscales, such as tension, anger and depression [10]. An example is the prevention of type A risk behavior in aerobic PA in nature [24]. This type of behavior is higher in people with increased neuroticism and is associated with a higher prevalence of coronary heart disease. Outdoor adrenaline sports activities are a means of psychotherapy, but also experiential pedagogy [25]. The review and analysis of the type of PA in nature associated with strengthening psychological well-being or mental health provides opportunities for further scientific research.

\section{Conclusions}

During the last two decades of research in the field of mental health and well-being and its associations with PA and the natural environment, solid and unambiguous knowledge has been obtained about the impact of nature and PA on mental health. However, despite extensive original research leading to many meta-analyses and systemic reviews, we cannot clearly point to a conclusive effect of PA in nature on mental health compared to indoor PA. Reviewers have noted problems of heterogeneous study designs and a lack of quantitative findings, and have revealed gaps in the evidence for the long-term effects of PA in nature. Only a minority of research has been focused on monitoring the type and intensity of PA to improve individual indicators of mental health. We recommend unifying the terminology. Due to its semantic discrepancy, clear conclusions could not be made. Although relevant and representative scientific sources have been used in this narrative review, it is still a subjective, rather than systematic, selection of literature that points out weaknesses in this robustly researched area. 


\section{References:}

1. Capaldi CA, Dopko RL, Zelenski JM. The relationship between nature connectedness and happiness: a metaanalysis. Front Psychol. 2014; 5: 976. https://doi.org/10.3389/fpsyg.2014.00976

2. Diener E. Subjective well-being. In: Diener E., editor. The science of well-being: the collected works of Ed Diener. Vol. 37. New York: Springer; 2009. p. 11-58. https://doi.org/10.1007/978-90-481-2350-6_2

3. Pouso S, Borja A, Fleming LE, Gómez-Baggethun E, White MP, Uyarra MC. Contact with blue-green spaces during the COVID-19 pandemic lockdown beneficial for mental health. Science of The Total Environment. 2020 Nov 26; 143984. https://doi.org/10.1016/j.scitotenv.2020.143984

4. Gladwell VF, Brown DK, Wood C, Sandercock GR, Barton JL. The great outdoors: how a green exercise environment can benefit all. Extrem Physiol Med. 2013; 2: 3. https://doi.org/10.1186/2046-7648-2-3

5. World Health Organization. Investing in mental health [Internet]. Geneva: World Health Organization; 2003 [cited 2021 Jan 8]. Available from: https://www.who.int/mental_health/media/investing_mnh.pdf

6. Keniger LE, Gaston KJ, Irvine KN, Fuller RA. What are the benefits of interacting with nature?. Int J Environ Res Public Health. 2013; 10(3): 913-935. https://doi.org/10.3390/ijerph10030913

7. Hartig T, Mitchell R, de Vries S, Frumkin H. Nature and health. Annu Rev Public Health. 2014; 35: $207-28$. https://doi.org/10.1146/annurev-publhealth-032013-182443

8. World Health Organization. WHO guidelines on physical activity and sedentary behavior [Internet]. Geneva: World Health Organization; 2020 [cited 2021 Jan 8]. Available from: https://www.who.int/publications/i/ item/9789240015128

9. Piggin J. What is physical activity? A holistic definition for teachers, researchers and policy makers. Frontiers in Sports and Active Living. 2020 Jun 18. https://doi.org/10.3389/fspor.2020.00072

10. Barton J, Pretty JN. What is the best dose of nature and green exercise for improving mental health? A multistudy analysis. Environ Sci Technol. 2010; 44(10): 3947-3955. https://doi.org/10.1021/es903183r

11. Yeh HP, Stone JA, Churchill SM, Wheat JS, Brymer E, Davids K. Physical, psychological and emotional benefits of green physical activity: an ecological dynamics perspective. Sports Med. 2016; 46(7): 947-53. https://doi. org/10.1007/s40279-015-0374-z

12. White RH, Babic MJ, Parker PD, Lubans DR, Astell-Burt T, Lonsdale C. Domain-specific physical activity and mental health: a meta-analysis. American Journal of Preventive Medicine. 2017; 52(5): 653-666. https://doi. org/10.1016/j.amepre.2016.12.008

13. Brymer E, Davids K, Mallabon L. Understanding the psychological health and well-being benefits of physical activity in nature: an ecological dynamics analysis. Ecopsychology. 2014; 6(3): 89-197. https://doi.org/10.1089/eco.2013.0110

14. Rogerson M, Wood C, Pretty J, Schoenmakers P, Bloomfield D, Barton J. Regular doses of nature: the efficacy of green exercise interventions for mental wellbeing. International Journal of Environmental Research and Public Health. 2020; 17(5): 1526. https://doi.org/10.3390/ijerph17051526

15. Thompson Coon J, Boddy K, Stein K, Whear R, Barton J, Depledge MH. Does participating in physical activity in outdoor natural environments have a greater effect on physical and mental wellbeing than physical activity indoors? A systematic review. Environ Sci Technol. 2011; 45(5): 1761-1772. https://doi.org/10.1021/ es102947t

16. Eigenschenk B, Thomann A, McClure M, Davies L, Gregory M, Dettweiler U, et al. Benefits of outdoor sports for society. A systematic literature review and reflections on evidence. International Journal of Environmental Research and Public Health. 2019; 16(6): 937. https://doi.org/10.3390/ijerph16060937

17. Lahart I, Darcy P, Gidlow C, Calogiuri G. The effects of green exercise on physical and mental wellbeing: a systematic review. Int J Environ Res Public Health. 2019; 16(8): 1352. https://doi.org/10.3390/ ijerph16081352

18. Bélanger M, Gallant F, Doré I, O'Loughlin JL, Sylvestre MP, Nader PA, et al. Physical activity mediates the relationship between outdoor time and mental health. Preventive Medicine Reports. 2019 Dec; 16: 101006. https://doi.org/10.1016/j.pmedr.2019.101006

19. Haskell WL, Lee IM, Pate RR, Powell KE, Blair SN, Franklin BA, et al. Physical activity and public health: updated recommendation for adults from the American College of Sports Medicine and the American Heart Association. Medicine and Science in Sports and Exercise. 2007; 39(8): 1423-1434. https://doi.org/10.1249/ mss.0b013e3180616b27

20. Burnet K, Kelsch E, Zieff G, Moore JB, Stoner L. How fitting is F.I.T.T.?: a perspective on a transition from the sole use of frequency, intensity, time, and type in exercise prescription. Physiology \& Behavior. 2019; 199: 33-34. https://doi.org/10.1016/j.physbeh.2018.11.007 
21. Meredith GR, Rakow DA, Eldermire ERB, Madsen CG, Shelley SP, Sachs NA. Minimum time dose in nature to positively impact the mental health of college-aged students, and how to measure it: a scoping review. Front Psychol. 2020; 10: 2942. https://doi.org/10.3389/fpsyg.2019.02942

22. McMahan EA, Estes D. The effect of contact with natural environments on positive and negative affect: a meta-analysis. J Posit Psychol. 2015; 10(6): 507-519. https://doi.org/10.1080/17439760.2014.994224

23. White MP, Alcock I, Grellier J, Wheeler BW, Hartig T, Warber SL, et al. Spending at least 120 minutes a week in nature is associated with good health and wellbeing. Sci Rep. 2019; 9(1): 7730. https://doi.org/10.1038/ s41598-019-44097-3

24. Zusková K, Górny MP. Aerobic physical activity in nature as compensation for a type behavior. Physical Education, Sports and Health Culture in Modern Society. 2019; 48(4): 55-60. https://doi.org/10.29038/22207481-2019-04-55-60

25. Kirchner J. [Psychology of experience and adventure: for pedagogy and psychotheraphy]. Brno: Computer Press; 2009 (in Czech). 